\title{
Comparative Studies of Brown Discoloration and Ammonia Liberation from the Milk Proteins by Ultraviolet Light Irradiation
}

\author{
By Sadao Sakamura and Yataro Obata \\ Department of Agricultural Chemistry, Faculty of Agriculture, Hokkaido University \\ Received August 1, 1958
}

\begin{abstract}
Investigations were undertaken on $\alpha-\beta$-casein, $\beta$-lactoglobulin and $\alpha$-lactalbumin isolated from fresh milk to ascertain the development of color and ammonia liberation when exposed to ultraviolet light.

Experimental data showed that $\alpha^{-}, \beta$-casein equally contributed to cause considerable brown discoloration, followed by $\alpha$-lactalbumin, while $\beta$-lactoglobulin remained almost colorless. Furthermore, additional evidence in a model system suggested that the participation of tryptophan is very important in such a discoloration.

On the other hand, some discussion is offered together with the suggestion that the liberation of ammonia might initiate from histidine residue without hydrolysis of linkage of peptide in protein.
\end{abstract}

In previous papers ${ }^{1,2)}$ attention has been drawn to the physico-chemical difference between the intact protein prepared from milk and denaturated protein exposed to UV-light.

In connection with the application of ionizing radiation for milk ${ }^{3}$, the browning and the occurrence of objectionable aroma and flavors in the protein solution irradiated by UV-light has made it desirable to direct particular attention to this matter.

Thence, some investigators have noted on the color production in their proteins by irradiation, but the nature of the compounds responsible for such a color has not yet been elucidated. Similarly to the case of browning a few reports concerning the determination of ammonia formed frec amino acids by UVradiation have appeared but only few reports about proteins are available . So it is of

1) Y. Obara and S. Sakamur, J. Agr. Cbem. Sor. Japan, 32, 251 (19584.

2) S. Sakamura and Y. Obata, J. Agr. Cbem. Soc. Jazpzn, 32, 667 (1958).

3) For example, J. H. Werthein, R. N. Roychoudhury, J. Hoff, S. A. Goldblith, and B.E. Proter, J. Agr. Food Chem., 5, 94t (1957).

4) A. D. Mclaren, Advances in Enzymology, 9, 75 (1949). course, not proven what nitrogen compounds in protein are susceptible of the splitting off ammonia.

In this work, the following facts were confirmed. When exposed to UV-light, $\alpha$ - and $\beta$-casein are comparatively more responsible and $\alpha$-lactalbumin is somewhat less, whereas $\beta$-lactoglobulin is almost not at all responsible for browning among the four representative proteins of cow's milk. With support from the result of model system experiments, the most important compound to which the browning may be ascribed is considered to be tryptophan residue rather than tyrosine or phenylalanine residue, but both of the latter can not be disregarded as a factor because they become susceptible to coloration only after tryptophan is eliminated.

It is also confirmed that lactose, which is the main carbohydrate in milk, does not cause any discoloration under the same conditions irrespective of the way it may be decomposed.

\section{EXPERIMENTAL}

Materials and Methods Fresh pooled whole-milk 
taken from several cows was used throughout. $\alpha-, \beta-$ casein were prepared according to the method of Warner; their homogeneity was electrophoretically ascertained. $\beta$-Lactoglobulin was recrystalized two times and lyophilized for preservation until use. The purity of the protein has been described in the previous paper. $\alpha$ Lactalbumin was purified the same run as used for the preparation of $\beta$-lactoglobulin according to the method of Aschaffenburg ${ }^{5)}$. It was not crystallized but lyophilized following dialysis against distilled water in a celophan bag at room temperature for a long time and was made electrophoretically homogeneous under the applied condition ( $\mathrm{pH} 6.8$, phosphate buffer). In most of these experiments amino acids obtained from Ajinomoto Co. were used without further purification. All of the acetyl amino acid derivatives were prepared by using acetic anhydride and were checked by melting point. Glycyl-L-tyrosine and glycyl-L-tryptophan commercially available were purchased. Glutamine was isolated from beet roots according to the description of Vickery et al. ${ }^{6)}$ and identified by showing m. p. $184^{\circ}$. All other compounds were synthesized in this laboratory, particularly, L-isoleucyl-L-valine and its anhydride were synthesized by Mizutani ${ }^{7}$.

Exposure to UV-light All of the samples were dissolved in phosphate buffer $\mathrm{pH} 6.8$, ionic strength 0.1 , to give a $1 \%$ concentration of protein or $0.2 \%$ of amino acid and amino acid derivatives individually. Each of the open Petri dishes (diameter, $50 \mathrm{~mm}$ ) containing $10 \mathrm{ml}$ of the solution was subjected to UVradiation at a $150 \mathrm{~mm}$ distance under a light source of ACME HOME SUNLIGHT (100v., 2 amp.) for fourteen hours. Temperature of the solution did not exceed above 15 .

Measurement of Degree of Brown Color and Ammonia Liberation The samples radiated as described above showed a decrease in water content and so, before measurement distilled water was added to fill the contents up to the original level. Color measurement was carried out by comparing the absorption coefficient using a Beckman type spectrophotometer (Hitachi Co.) in the region of visible light.

Ammonia was colorimetrically determined by the micro-diffusion method with Conway's unit ${ }^{8}$.

\section{Qualitative Analysis of N-Terminal of Protein}

5) R. Aschaffenburg and J. Drewry, Biocbem. J., 65, 273 (1957). 6) H. B. Vickery, G. W. Pucher and H. E. Clark, J. Biol. Cbem., 109, 39 (1935).

7) Y. Obara and J. Mizutani, in press.

8) B. E. J. Conway, Micro-diffusion Analysis and Volumetric Error, 2nd, ed., London, Crosby, Lockwood and Sons. with DNFB* The dinitrophenyl derivatives of the proteins ( $\alpha$-casein and $\beta$-lactoglobulin) were prepared by Sanger's method ${ }^{20}$. Two hundred $\mathrm{mg}$ of protein dissolved in water or buffer, or $10 \mathrm{ml}$ of irradiated solution was allowed to react with $0.5 \mathrm{ml}$ of DNFB in ethanol containing $0.5 \mathrm{~g}$ sodium bicarbonate. The mixtures were shaken mechanically for four hours at room temperature. The resulting mixture was slightly adjusted to the acidic side by adding dilute hydrochloric acid. DNP-proteins precipitated were centrifuged, washed with ethanol and ether, finally dried in the exicator over phosphorous pentoxide in vacuo. DNP-protein was hydrolysed by autoclaving with $6 \mathrm{~N}$ hydrochloric acid at $110^{\circ}$ in a sealed glass tube for ten hours. The hydrolysate was divided into the ethersoluble fraction and the residue (water-soluble fraction). The latter was evaporated to dryness under reduced pressure and redissolved with water or extracted with ethyl methyl ketone. Both fractions were individually chromatographied using filter paper ${ }^{10)}$ and silica gel which was made of sodium silicate ${ }^{(9)}$. Authentic DNPamino acids employed for comparison were also synthesized and purified by the present authors.

\section{RESULTS AND DISCUSSION}

Brown Discoloration. It must be stated that lactose did not cause any coloration in these model experiments. As shown in Fig. 1, all of the proteins contributed to the yellowish brown discoloration by exposure to UV-light. But the order of color intensity was as follows: $\alpha-\beta$-casein $>\alpha$-lactalbumin $>\beta$-lactoglobulin; the last one scarcely became brown. Thus, it was presumed that such a discoloration might be attributable to amino acids. The effect of UV-light exposure on various amino acids and on their derivatives was therefore compared under the same conditions. The results are shown in Fig. 2. Tryptophan, even the amino group of which some members were acetylated, was most intensively brown-colored. When compared with glycyltyrosine and glycyltryptophan, the latter became definitely much more

* The following abbreviations in this paper indicate, DNP: 2, 4-dinitrophenyl group; DNFB : 1, 2, 4-dinitrofuorobenzene.

9) F. Sanger, Biochem. J, 39, 507 (1949). S. Mizushima and S. Akabori, Chem. of Protein, Kyoritsu Shuppan Co., Vol. 4 (1956) p. 209.

10) E. F. Melon, A. H. Korn and S. R. Hooper, J. Amer. Chem. Sor., 75, 1675 (1953). 


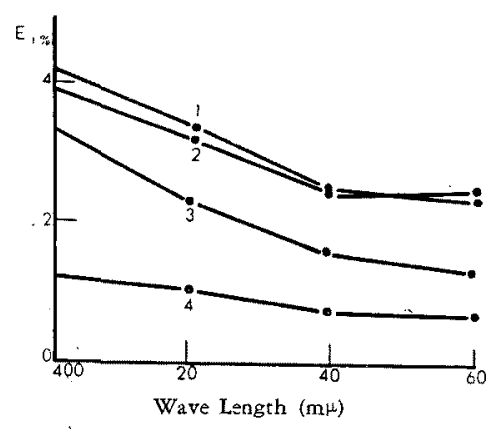

FIG. 1. Comparison of the Color Development from the Proteins in $1 \%$ Solution in Phosphate Buffer ( $\mathrm{pH}$ 6.8) upon UV-Radiation.
1) $\alpha$-Casein
3) $\alpha$-Lictalbumin
2) B.Casein
4) $\beta$-Lactoglobulin

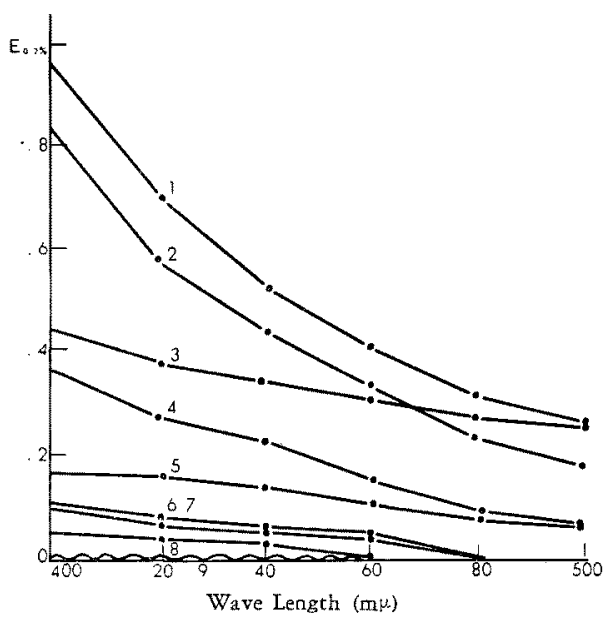

FIG. 2. Comparison of the Color Development from the Various Amino Acids and their Derivatives in $0.2 \%$ in Phosphate Buffer (pH 6.8) upon UV-Radiation.

$\begin{array}{ll}\text { 1) Tryptophan } & \text { 6) } \text { Cystine } \\ \text { 2) Na-Acetyltryptophan } & \text { 7) Histidine } \\ \text { 3) Tyrosine } & \text { 8) Hydroxyproline } \\ \text { 4) Phenylalanine } & \text { 9) Other Amino Acids } \\ \text { 5) N.Aceryltyrosine } & \end{array}$

brown than the former.

These results suggest that tryptophan residue is a most important factor for the browning, though tyrosine and phenylalanine may participate partly in the discoloration only after tryptophan is eliminated. However, there is a fact that $\beta$-lactoglobulin hardly causes such a discoloration in spite of the existence of tryptophan. This point, now seems to be explicable as a protective action in sulfhydryl group of peptide chain or as protective influence due to some unknown spatial arrangement.

Liberation of Ammonia. As shown in the previous paper, the present authors observed that the liberation of ammonia from $\beta$-lactoglobulin undoutedly took place, even though ammonia was obtained from $\alpha$-casein in the experiment which was carried out in detail

TABLE I. YIELDS OF AMMONIA OBTAINED FROM AMINO ACIDS AND OTHER RELATED COMPOUNDS IN $0.2 \%$ IN Phosphate Buffer (pH 6.8) UPON UV-RADIATION

\begin{tabular}{|c|c|}
\hline Compounds & $\mathrm{NH}_{3}(\mu \mathrm{Mol} / \mathrm{ml})$ \\
\hline Glycine & 0.50 \\
\hline Alanine & 0.70 \\
\hline Threonine & 0.64 \\
\hline Valine & 0.59 \\
\hline Leucine & 0.46 \\
\hline *Cystine & 0.94 \\
\hline Methionine & 0.68 \\
\hline Proline & 0.37 \\
\hline Glutamine & 0.48 \\
\hline Asparagine & 0.45 \\
\hline Glutamic Acid & 0.37 \\
\hline Aspartic Acid & 0.36 \\
\hline Butyramide & 0.13 \\
\hline Valeramide & 0.25 \\
\hline Phenylalanine & 0.30 \\
\hline *Tyrosine & 0.40 \\
\hline Tryptophan & 0.20 \\
\hline Histidine $\cdot \mathrm{HCl}$ & 1.40 \\
\hline Lysine $\cdot \mathrm{HCl}$ & 0.64 \\
\hline Arginine & 0.33 \\
\hline Acetylglycine & 0.15 \\
\hline N-Acetyltyrosine & 0.33 \\
\hline $\mathrm{N}^{\alpha}$-Acetyltryptophan & 0.15 \\
\hline Isoleucylvaline & 0.45 \\
\hline *Isoleucylvaline Anhydride & 0.19 \\
\hline ** $\beta$-Lactoglobulin & 0.30 \\
\hline$* * \alpha$-Casein & 0.19 \\
\hline Skim Milk & 1.13 \\
\hline
\end{tabular}


later. Thus, in order to establish what kind of nitrogen-containing compound in protein is responsible for the liberation of ammonia, determinations of free ammonia were made on solutions of various amino acids and their derivatives after exposure as described above. The results of such determinations are shown in Table I, data of which are presented with an increased amount of ammonia liberated upon irradiation. Histidine produced the greatest amount of ammonia, followed by cystine, methionine etc., whereas amino acid amide liberated was in an extremely small extent. On the other hand, ammonia from $\beta$-lactoglobulin was calculated to be $\mathrm{ca} 1 \mathrm{~mol}$ per molecule on the basis of 35,000 molecular weight ${ }^{11)}$. Therefore, it seems to be possible that liberation of ammonia in the protein mostly originates from histidine and only partly from others.

DNP-Amino Acid If the peptide linkage of protein is hydrolysed on UV-radiation as was postulated by Carpenter ${ }^{12}$, the hydrolysation is most likely expected to result in alternation on the $\mathrm{N}$-terminal amino acids of the protein

Table II. Results of Paper Chromatography OF DNP-AMINO ACIDS FOUND IN $\alpha$-CASEIN IRRADLATED AND NOT IRRADIATED

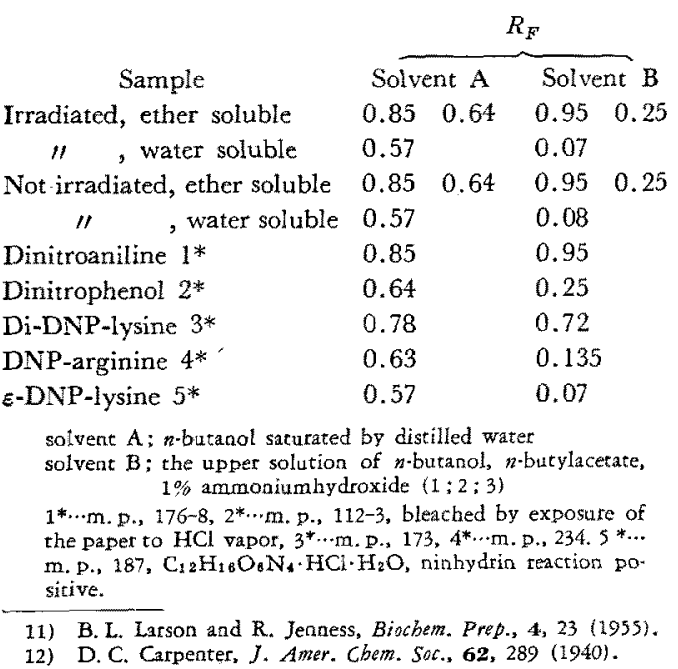

TABle III. RESUlts of PAPER Chromatography OF DNP-AMINo ACIDS FOUND IN $\beta$-LACTOGLOBULIN IRRADIATED AND NOT IRRADIATED

\begin{tabular}{|c|c|c|}
\hline \multirow[b]{2}{*}{ Sample } & \multicolumn{2}{|r|}{$R_{F}$} \\
\hline & Solvent $\mathrm{A}$ & Solvent $\mathrm{B}$ \\
\hline Irradiated, ether soluble & & $0.94,0.51,0.31$ \\
\hline , water soluble & 0.67 & 0.064 \\
\hline Not Irradiated, ether soluble & & $0.94,0.51,0.31$ \\
\hline , water soluble & 0.66 & 0.06 \\
\hline Dinitroaniline & & 0.94 \\
\hline Dinitrophenol & & 0.30 \\
\hline DNP-Leucine* & & 0.51 \\
\hline$\varepsilon$-DNP-lysine & 0.67 & 0.059 \\
\hline
\end{tabular}

in both qualitative and quantitative sence. As shown in Tables II and III, DNP-amino acid was identified as DNP-leucine and $\varepsilon$-DNPlysine in both intact and irradiated $\beta$-lactoglobulin, and as $\varepsilon$-DNP-lysine only in both cases of casein, although their values were not determined.

Further research efforts were directed toward paper chromatographic identification of the radiation-breakdown products from model compound, such as glycyltyrosine, glycyltryptophan, in order to obtain additional evidence whether hydrolysis of peptide linkage occurs

TABLE IV. RESULTS OF PAPER GHROMATOGRAPHY OF COMPOUNDS INDUCED FROM GLYCYL-L-
TYROSTNE AND GLYCYL-L-TRYPTOPHAN
BY EXPOSURE TO UV-LIGHT

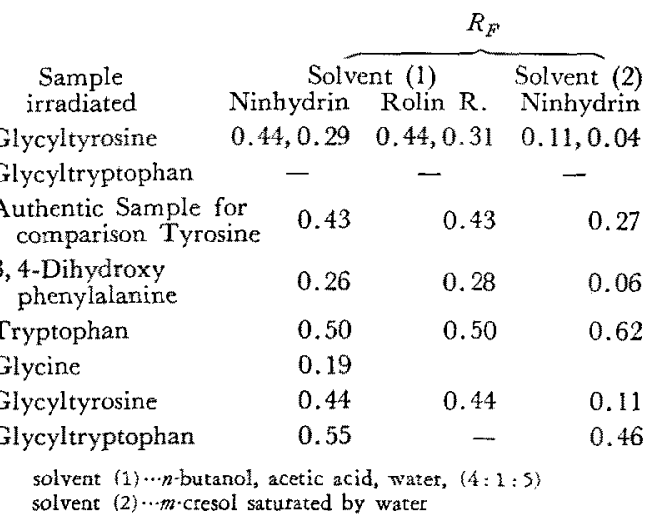


or not. The results are shown in Table IV. The radiation conditions were essentially the same but on a smaller scale than that described in the section of the present paper, that is, $2 \mathrm{mg}$ of sample was contained in $10 \mathrm{ml}$ distilled water, exposure for four hours, followed by concentration at reduced presure at room temperature. No spot of expected amino acid from hydrolysis of glycyltyrosine was detected, but an unidentified spot different from that of the original peptide, not found in the control, was detected on the paper chromatograms. It gave a blue color with Folin reagent ${ }^{13)}$, and a positive reaction with ninhydrin, the color of which was somewhat yellow and after only a little while turned purple resembling that of the original peptide.

Accordingly, the above facts suggested the occurrence of an oxidized compound maintaining the peptide linkage such as glycyl-3,4dihydroxyphenylalanine. On the other hand, in the case of glycyltryptophan neither a newly produced spot nor the original spot could be detected on paper chromatograms by either reaction but the browning of the solution was more intense than that resulting from glycyltyrosine.

Concerning the effect of UV-radiation on free tyrosine and tryptophan, the above described observations led to the detection of dopa and kynurenine individually, in accordance with the case of exposure to sunlight ${ }^{18,14)}$.

13) Y. Obata and S. Sakamura, J. Agr. Chem. Soc. Japan, 27, 769 (1953).

14) S. Sakamura and Y. Obata, J. Agr. Chem. Soc. Japan, 29, 616 (1955). 